Cornell Law Library

Scholarship@Cornell Law: A Digital Repository

Pragmatism, Law and Governmentality

3-28-2003

\title{
Pragmatist and Non-pragmatist Knowledge Practices in American Law
}

Mariana Valverde

Centre of Criminology, University of Toronto, m.valverde@utoronto.ca

Follow this and additional works at: http://scholarship.law.cornell.edu/ealccs_plg

Part of the Jurisprudence Commons

\section{Recommended Citation}

Valverde, Mariana, "Pragmatist and Non-pragmatist Knowledge Practices in American Law" (2003). Pragmatism, Law and Governmentality. Paper 1.

http://scholarship.law.cornell.edu/ealccs_plg/1 


\section{PRAGMATIST AND NON-PRAGMATIST KNOWLEDGE PRACTICES IN AMERICAN LAW}

Mariana Valverde, Centre of Criminology, University of Toronto

m.valverde@utoronto.ca

Paper for Cornell conference on pragmatism, March 28, 2003.

\section{The epistemological heterogeneity of legal networks}

- these initial comments are off the cuff and tentative, and meant to generate discussion, not to count as my definite analysis

For anyone interested in documenting and analyzing knowledge practices, legal arenas prove to be fruitful sites, for at least two reasons. 1) First, questions of evidence and of authority are often explicitly contested, with the contestations often forming part of a court's public record and/or going on in the public setting of the courtroom. Thus, unlike science studies scholars, who must gain access to social interactions that are not mentioned in scientific papers and that do not take place in public view, legal studies scholars have vast amounts of material - affidavits, trial transcripts, etc- that can readily be analyzed, and we have automatic access to at least some of the struggles about what counts as evidence and who counts as an authority waged in legal settings. While recognizing that interviews and ethnographic methods can offer very important insights, and acknowledging that 'the public record' is the product of a whole set of prior practices which are either black boxed or simply invisible, nevertheless, it seems to me that sociologists and anthropologists of knowledge should not neglect to explore processes that are readily accessible either through court observation or through the written public record of legal proceedings.

I suspect that this is not merely a practical matter of access to data; it may be that the public character of many of the evidentiary disputes and processes in law itself becomes an actor, in ways that to my knowledge have not been mapped. The debates (particularly heated in the US since the passing of the Patriot Act and other antiterrorist legislation) about how to draw the line separating publicly accessible from secret legal or law enforcement knowledge processes have been analyzed from the point of view of the politics of the rule of law; but they could also be analyzed from an actor-network standpoint.

Secondly, legal arenas, particularly in common-law jurisdictions, are characterized by the simultaneous coexistence of radically heterogeneous and uncoordinated epistemologies. That civil lawsuits are adjudicated using a different standard of proof than criminal cases is known to most people, and certainly to every law student. But it is less well known that this is only one of a large number of epistemological heterogeneities that can be documented even staying in a single courtroom or confining oneself to one type of case. Those of us who are beginning to borrow and adapt some tools from Science and Technology Studies for use in analyzing legal processes may be able to return the favour by highlighting the jurisdictional and other devices that allow 'law' to retain its legitimacy despite the fact that conflicting modes of reasoning and very different standards of proof coexist happily, in a state that a 
scientific mind would describe as epistemological anarchy. This is not to say that other fields are necessarily unified or somehow coordinated; but it is my suspicion that legal arenas exhibit a particularly cavalier stance toward existing epistemological heterogeneity.

\section{Pragmatic knowledge practices - the example of urban law}

Neither I nor anyone else I know has done or is likely to do a full inventory of the wide variety of knowledge practices that enable law to do its work. I have done a bit of this mapping work in a book that will be published by Princeton soon (Law's Dream of a Common Knowledge) that looks at several 'gazes', authority structures and evidentiary processes that are all located in a 'no man's land' lying in between the expert knowledges studied in 'science and the law' works, on the one hand, and on the other hand, the experiential knowledge of law deployed by ordinary people in everyday interactions, the knowledge mapped over the past fifteen years or so by scholars working in the 'everyday life of law' tradition (B. Yngvesson, S. Merry, P. Ewick and S. Silbey, D. Engel, etc.) The knowledge practices mapped in my book lie in an in-between realm, one in which both expertise and everyday experience are invoked and used, but in networks which follow logics that are neither those of expert fields or those of authentic everyday experience. A number of information formats and coding practices are found to enable mainly administrative knowledges of order and disorder, virtue and vice, in legal arenas from indecency trials to liquor inspections to urban zoning law.

One of these low-level administrative knowledge formats, ubiquitous in urban regulation and law, is what I call 'the epistemology of the list'. This format operationalizes regulatory, often preventive, governance projects with little or no theoretical justification, through the purely metonymic technique of the list. Form cannot be totally divorced from content, however, and so it is necessary to briefly summarize the content of municipal law in a very general way.

In common-law jurisdictions, municipal order, in the $21^{\text {st }}$ as in the $18^{\text {th }}$ century, can be said to be composed of the following rationalities: 1) the production and reproduction of hygiene, efficient transportation, and commercial relations that are free from crime and immorality (or to use the legal phrasing, "health, safety, and public morals"); 2) the protection and regulation of commercial property and private residential property; and 3) the provision and enhancement of public spaces and public facilities.

These are heterogeneous aims and competences, irreducible to one another or to a common denominator. The irreducibly plural nature of municipal order, I am (tentatively) arguing, is the feature that most clearly distinguishes it from state order. While state order is also plural, nevertheless, it is not incorrect to follow Weber and highlight sovereignty, over territory and over subjects, as the indispensable state rationality. Municipal order, by contrast, does not suffer from territorial and symbolic anxieties. Exit visas and charges of treason are not municipal legal tools. Citizens have generally had pragmatic reasons for remaining in cities or moving to other cities, and this movement has not generally been subject to legal regulation, in modern times at any rate. And authorities governing cities have, since the $18^{\text {th }}$ century, emphasized the practical everyday basis of civic life - the need for good sewers, proper street lighting, adequate garbage disposal, sanitary housing, and so on. ${ }^{1}$

\footnotetext{
${ }^{1}$ The practical everyday dimension of urban governance acts as justification to dismiss the field as uninteresting and untheoretical. Law school curriculums today re-enact the subordination of the plural-urban effected by Adam Smith, a key founder of modern state knowledges: police, he states, "only means the inferior parts of government, viz., cleanliness, security, and cheapness or plenty. The two former, to wit, the proper method of carrying dirt from the streets, and the execution of justice, are too mean to be considered in a general discourse of this kind." (Smith, Lectures on justice, police, revenue, and arms [1763] 1896, 154).
} 
The pragmatic and plural objectives and rationalities of city governance parallel the formal features of a knowledge format that, while not unique to urban/municipal law, is certainly typical of this area of law: the unprioritized list of heterogeneous, unconnected risky problems and activities.

Bill Novak's book on municipal police powers in American legal history (Novak 1996) opens with just such a list of municipal objects of regulation - the list, still found in municipal websites today, that simply goes from one potentially risky or criminogenic activity, space, or occupation to another, with no apparent rhyme or reason. Pawnshops, carriages for hire, drinking establishments, fireworks factories, and slaughterhouses are some of the spaces highlighted for municipal regulation; while second-hand clothes dealing, playing music in the streets, running a metal-working shop, are some of the numerous potentially risky activities that are listed - without any rationale as requiring special supervision (licensing, usually). Chicago in 1837 is Novak's particular example; but very similar lists exist throughout the domain that the eighteenth century called 'police' (as in 'police regulations'). Charles Reich, writing in 1964, tells us that the New York Commissioner of Licences had responsibility for the following problem spaces and activities (and note the order, or lack of it, of this list):

...exhibitions and performances, billiard and pool tables, bowling alleys, miniature golf, sidewalk cafes and stands, sightseeing guides, street musicians, public carts, expressmen, porters, junk dealers, second-hand dealers, pawnbrokers, auctioneers, laundries, wardrobe concessionaries, locksmiths, masseurs, bargain sales, bathhouse keepers, rooming houses, barbers, garages, refuse removal, cabarets, coffee houses, and cannon firing. (Reich 1964, 759).

And in Toronto today, hair salons, pizza parlours, tattoo parlours, taxis, massage businesses, and pawn shops are only some of the many types of businesses that are subject to special licensing requirements. Intrusive or onerous obligations are imposed, through the legal device of 'conditions of the licence', that could not normally be imposed on law-abiding, non-convicted citizens. E.g. in Toronto, pawnshops have to submit a copy of all of their transaction records on a daily basis to the local police, as a condition of their licence; and in some US states, getting a licence as a barber requires producing evidence of 'good character'?

Seeeing like a city, ${ }^{3}$ then, involves a certain type of ordering. Problem spaces and activities are listed in no particular order, and many of these are monitored and risk-managed 'at a distance' by subcontracting vigilance to the very private sector agents that produce the risks in the first place. Vigilance here is thus not effected through the better known mechanisms of centralized data banks, "avalanches of printed numbers" (Hacking), and medical or quasi medical examinations. I do not here have the space to go through my empirical studies of licensing, but elsewhere I have shown that, contrary to what one would expect if immersed in reading Mary Poovey, James Scott, or for that matter Michel Foucault, the epistemology of the unprioritized, untheorized list of risky spaces and activities is not likely to be driven out any time soon by the better known gaze of centralizing experts using scientific knowledge formats. ${ }^{4}$

\section{The uneven and contradictory development of pragmatic and antipragmatic knowledge practices}

\footnotetext{
${ }^{2}$ Supreme Court of New York, New York County 2003 NY Slip Op 23444.

${ }^{3}$ By referencing James C Scott's Seeing Like A State I merely want to highlight the specificity of urban ordering practices; I am by no means subscribinb to his romanticized view that 'small is beautiful' and that the main danger to human happiness is the state's centralizing and expert-driven gaze.

${ }^{4}$ See M Valverde, "Police science, British style: Pub licensing and the governance of urban order" in press Economy and Society, 2003; also, chapters 6 and 7 of Law's Dream of a Common Knowledge (Princeton, spring 2003).
} 
A thorough study of minor practices of municipal governance of spaces and activities would very likely support an argument about the persistent power of hybrid administrative knowledges of urban risks - knowledges which may use bits of science but which are not scientifically formatted, do not seek to gather aggregate data and use that data to reform governance, and do not require or produce 'experts' in the usual sense (nuisance inspectors and licensing tribunal members are not experts in either the legal or the everyday meaning of the term). In much of my work I have been and remain interested in mapping this hybrid epistemological realm. Nevertheless, I want to avoid the James Scott fallacy of dividing knowledge practices by means of a binary opposition. Local knowledges of street disorder, for example, are certainly different from epidemiological or environmental-science knowledges of risk: but the local knowledges in question do not necessarily have any automatic affinity for resistance or for authenticity.

There are heuristic and political reasons for sometimes contrasting 'local' knowledges to state and/or expert knowledges, to the latter's detriment; but not only is it wise to beware of romanticizing premodern knowledge practices, but, it is also important to attend to the ways in which knowledge practices that are primarily associated with one or another pole of a binary opposition (state vs local, expert vs experiential, etc.) proliferate and are adapted for use in any number of settings. Actually existing networks are rarely accurately represented by labels that abstract one particular logic or knowledge mode out of the network. In the field I am now beginning to study (municipal regulation and urban law), local knowledges of disorder, whether mobilized by citizens or by minor officials from dog catchers to nuisance inspectors, not only coexist with state knowledges but are intertwined with them.

The easy mixing of commonsense knowledge of order and risk, marketing knowledge of customer preferences, and legal knowledge of urban law-in-action (plus a tiny bit of quasi medical knowledge about the risks of rotten food) is easily visible in a series of interviews with sidewalk hot dog vendors that a research assistant, Cherie Leung, has been conducting for me. That fried onions are illegal while sauerkraut is not is just one of the fascinating bits of information about this particular sociolegal arena that has emerged from this - but I do not yet know whether this rule originally came out of the public health department or from the licensing inspectors' own common law.

The anti-theoretical, vaguely pragmatic pluralism that is characteristic of urban governance, and which I have argued is effected in part through the technique of the list, can and does coexist with rationalities and knowledge formats that are much more centralizing, and which facilitate political sovereignty, national-moral symbolism, legal formalism, and/ or biopolitical rationalities. It may be that, in general, there is no reason to assume a zero-sum relation between one type of knowledge format, or one rationality of governing, and rationalities and technologies of knowledge which may be different but are not necessarily opposite.

The assumption that knowledge formats and rationalities fall into binary opposites is of course a common one. In legal networks, there is a longstanding tendency to contrast formalism, on the one hand, to some opposite, sometimes described as 'realism'. Legal realism is, or was, an umbrella term for legal scholarship that, especially around the 1930s, attempted to provide alternatives to formalism and legalism by opening up the definition of law (e.g. to include Native American dispute resolution mechanisms) and simultaneously opening up existing legal arenas to social science information about changes in US society.

I am not sufficiently familiar with the intellectual history of American law to be able to specify the relationship between legal realism and philosophical pragmatism, but there is clearly an influence, possibly one that is mostly mediated through other, non-philosophical knowledges (economics and management, I suspect). But, speaking very broadly and imprecisely, it is not inaccurate to say that pragmatic tendencies and practices in American legal 
scholarship and judicial practice (e.g. the jurisprudence of the New Deal Supreme Court) have generally been regarded as connected to, and justified by, the philosophical legacy of American pragmatism, on the one hand, and the scientific legacy of economic and social science on the other - and the resulting entity, whether called realism, pragmatism, of 'law and society studies', has gained much of its identity through being contrasted with formalism.

Whatever the relationship betwen pragmatism as a theory and pragmatic practices of power/knowledge might have been in the era of the New Deal, the fact is that today there is no such thing as 'legal pragmatism' as a coherent movement within US law and jurisprudence. It is thus more fruitful to sideline pragmatism and turn instead our attention to the welter of knowledge practices used in legal arenas or for legal purposes. The question then becomes whether it is possible to identify the dynamic linking pragmatically oriented or pragmatically driven knowledge practices (here using 'pragmatic' more or less in its everyday sense) and practices that are resolutely antipragmatic - e.g. the persistent belief that every new social problem (from 'date rape' to synthetic recreational drugs) requires the drawing up of a new criminal law, in order to "send a message" and to reassert the national moral consensus. ${ }^{5}$

An assumption made by some of the proponents of legal realism and/or legal pragmatism was/is that in the twentieth century American law would become more pragmatic and less symbolic/ moral. Law would become more regulatory and less coercive, becoming more concerned about managing risks than about asserting sovereignty. Technocrats would incorporate the findings of social and economic science into the law-making and adjudication processes. And so law would become more modern, more social, more responsive to changing economic conditions and modern, sociological ways of seeing problems of order.

It is tempting to use this technocratic thesis about legal pragmatism as a foil, almost as a straw man, and then proceed to document the ways in which, for various political and cultural reasons not anticipated in the era of the New Deal, law has failed to evolve as predicted, at least in criminal law. But while documenting the persistence or the renaissance of symbolism, moralism, and punitivism, and critiquing this from the standpoint of rational social science, is certainly politically necessary, it is intellectually problematic. Among other things, it assumes a zero-sum relationship between pragmatic and antipragmatic styles of thought. It is assumed that if law is becoming suffused with technocratic and other pragmatic rationalities and techniques of knowledge, then it is necessarily becoming less moralistic, symbolic, etc. The problem with this zero-sum paradigm is that it assumes that there is some invisible or visible hand that coordinates and harmonizes legal knowledge practices. Despite the highly hierarchical structure of courts and of statutes, legal knowledge practices are not articulated in a hierarchical unified system. The epistemological heterogeneity that characterizes law, mentioned at the outset, means that there is seldom direct competition among epistemologies and rationalities. Some areas of law or ways of using law might well be increasingly pragmatic, while others are going in the opposite direction. And since courts only look at particular cases, not at law as such, no coordination of knowledge practices is necessary. The rules and standards, as well as the judgements and statutes, do have to be arranged in some kind of order of precedence, but since there is no oneto-one relationship between a particular text and a particular way of knowing and arranging information, the immense labours that courts engage in so as to ensure consistency do not touch the epistemological anarchy that enables 'facts' to be entered into evidence, judged, evaluated, and distilled into a largely non-factual legal decision. ${ }^{6}$

\footnotetext{
${ }^{5}$ The utilitarian thinker Jeremy Bentham, who can be seen as an ancestor of pragmatism despite his centralizing bent, famously complained that members of Parliament were always imagining that if a rash of potato-stealing was taking place in the English countryside, it was necessary to pass some new law against potato theft, rather than simply use existing laws also covering onion stealing. [ref?]

${ }^{6} \mathrm{Cf}$ Bruno Latour on 'la fabrique du droit' - "Facts are things that one tries to get rid of as quickly as possible, in order to move on to other things, namely the particular point of law that is of interest" [from A Pottage translation, "Scientific facts and legal objectivity"]. Latour's analysis of legal facticity would not fit criminal trials, however,
} 
And each area of law is not in any case a unity, from the standpoint of method, of knowledge practices. Even within a particular legal field - even within one and the same judicial decision - it is possible to identify mechanisms that facilitate or effect a link between a pragmatic knowledge practice and an antipragmatic knowledge practice. Thus, legal arenas present us with a case of uneven and contradictory development - if the term 'development' can be applied at all, which I suspect is not the case.

Let me turn to a specific issue in US law that I have recently researched - special zoning requirements for sexually oriented establishments - to see just how pragmatic and non-pragmatic knowledge practices - rationalities, standards of proof, codes, etc - are in fact linked and connected. The conclusion, to anticipate, is that pragmatic rationales, justifications, and chains of reasoning are certainly very popular: but pragmatic justifications are often part of legal actor networks in which antipragmatic and/ or non-pragmatic logics ${ }^{7}$ live on and continue to be effective, seemingly undisturbed.

\section{Knowledge practices in the sexual zoning of cities}

Administrative knowledges mobilized to make such decisions as whether to grant a certain kind of street vendor a municipal licence or to reform the zoning regime are these days generally justified on pragmatic grounds, rather than on principled grounds (either scientific or legal or moral). The harm principle, as Bernard Harcourt has shown in an exhaustive study of recent American law (Harcourt 1999), is now used in a whole variety of legal arenas, including in those that were previously thought to turn on absolute moral codes. Municipal zoning and licensing law are no exceptions. The desire of traditional patriarchal nuclear families to isolate themselves in leafy suburbs, previously thought to be a sufficient ground to justify restricting other people's right to choose their abode, is no longer a sufficient ground to justify exclusionary zoning. ${ }^{8}$ Some legal authorities still use this antipragmatic, moral-highground rationale - most notably Justice Scalia, who writes (in May 2002): "The Constitution does not prevent those communities that wish to do so from regulating, or indeed entirely suppressing, the business of pandering sex." ${ }^{9}$ But no other justices subscribed to Scalia's judgement in that case (involving an impugned LA ordinance forbidding two porn shops from operating under the same roof); all the other judges declared that cities cannot totally suppress businesses involved in speech ${ }^{10}$, and that strict regulation of these businesses can be legally accomplished by city

arenas in which a fact, or indeed an object - a gun, a fingerprint - can indeed play a role similar to the neurons and rat brains of Latour's laboratory.

${ }^{7}$ I am purposively leaving the term 'pragmatic' quite indeterminate; but I would differentiate between knowledge practices that are incompatible with pragmatic rationales or styles of thought, on the one hand, and knowledge practices that are simply different ('nonpragmatic'), and which may or may not be able to coexist with pragmatic elements or actors.

${ }^{8}$ The classic case is the 1974 US Supreme Court decision in Village of Belle Terre v Boraas: "A quiet place where yards are wide, people few and motor vehicles restricted are legitimate guidelines in a land-use project addressed to family needs... The police power [i.e. regulatory power of municipalities] is not confined to the elimination of filth, stench, and unhealthy places. It is ample to lay out zones where family values, youth values [sic], and the blessings of quiet seclusion and clear air make the area a sanctuary for people." This was in keeping with the traditional definition of the state's police power (which in the US is supposed to lie literally with the state, not the federal government). In the much-quoted words of the great jurist William Blackstone, the police power is "the due regulation and domestic order of the kingdom, whereby the indiviudal of the state, like members of a well-governed family, are bound to conform their general behaviour to the rules of propriety, good neighbourhood, and good manners...." (Quoted in Neocleous 1998, 431).

${ }^{9}$ Scalia in City of Los Angeles v Alameda Books, 2002 WL 970712 (US)

${ }^{10}$ American law's way of drawing the distinction between speech and non-speech for First amendment law purposes is, incidentally, highly non-pragmatic; barbershops and hair salons, sites upon which important speech, including 
councils, but only if there is some evidence of harm.

But the more or less pragmatic, 'let's document the harm' approach, in the case of sex businesses, does not activate networks of scientific studies and rationalistic policy analysis - as it does in public health and environmental assessments, two areas of municipal competence which follow state and statistical logics rather than the epistemology of the list. Forcing municipal councils to take up pragmatism by using evidence of social harm to justify zoning or other municipal ordinances does not actually result in standardized, technocratically driven decision making. In the case of the special zoning requirements attaching to 'adult' (that is, pornographic) establishments, appeal courts have been happy to allow some municipalities to separate these establishments and isolate them through the 'thousand foot rule" ${ }^{11}$, whereas other municipalities follow the older sociolegal technology of the 'red light district'. Thus, invoking the utilitarian harm principle, which cities are now obligated to do, does not result in an objective, shared knowledge of harm to communities that in turn generates a specific 'best practices' policy (either separation or congregation).

What is particularly curious here is that the indeterminacy of the link between the harm principle and the actual policy followed is not said to arise from local particularities, even though that would be a traditionally legal way of allowing policy differences to coexist under a single pragmatic principle. Local particularities are in fact erased in the very legal network that empowers the local authority. City councils are empowered to choose between separating sex businesses or congregating them, and there is no need whatsoever for them to connect their policy choice to any local conditions, or to justify it through a local study.

Instead, what we see in this legal network is the circulation of particular studies - of this or that city- which are silently detached from their source and their context. Without being aggregated through a meta-analysis, they retain their status as particular studies; but anything local is legally irrelevant. A notable case in point is the (successful) invocation of a study of New York's Times Square and its sex indudstry by other municipalities lacking spaces that looked anything like Times Square - including the quiet Seattle suburb of Renton, which went all the way to the Supreme Court to get permission to very strictly regulate non-existent pornographic theatres and arcades (Renton $v$ Playtime Theatres 475 US 41 (1986). ${ }^{12}$

How do courts manage to simultaneously hold that, on the one hand, the harms of sexually oriented establishments are the same everywhere (by allowing evidence from anywhere to be introduced by municipalities) - and on the other hand, express no surprise that city councils come up with totally contradictory policies to regulate and control this supposedly univocal harm? This juggling feat is accomplished through an interesting, but heavily black boxed operation enabled by the legal instituiton of judicial review. Through this device, jurisdiction (legal capital) is quietly converted into epistemological currency. The majority decision in the 2002 Alameda books Los Angeles case, written by Justice O'Connor, is one text in which the traces of this exchange are visible.

O'Connor's text appears at first sight, to any social scientist, as a monster, since she uses the words 'correlation' and

political speech, notoriously takes place, cannot use the First Amendment to contest their special zoning regime, while nude dancing establishments can.

${ }^{11}$ Commonly, adult zoning ordinances require establishments to be at least 1000 feet from one another, and 500 feet from the nearest church or school. No particular justification has been offered in any of the cases examined for these two numbers, which again points to the easy coexistence of a knowledge practice that is totally arbitrary from a social science point of view with a vaguely social-scientific, vaguely Chicago notion of 'harm to communities'.

${ }^{12}$ Detroit was the site of the patient-zero case, Young (1976). Renton is the next major link in the line of Supreme Court cases that culminated in May 2002 in the Alameda Books case. 
'effect' interchangeably. But a closer reading reveals that the slippage between correlation and causality is not significant anyway - is not an actor - because the key point is said to be that the municipality had a reasonable belief, not whether the belief was true or scientifically valid: "it was therefore consistent with the [LA city planners] study's findings, and thus reasonable, for the city to infer that reducing the concentration of adult operations in a neighbourhood... will reduce the crime rates." A belief is reasonable if some evidence is cited to support it.

In a trial situation, evidence is scrutinized for its intrinsic 'weight' and for its compatibility with other evidence, and witnesses are scrutinized for their credibility. Criminal trial judges want to hear facts, not beliefs. But in the judicial review of administrative agency and municipal decisions, the knowledge standard is very different. O'Connor reminds the other judges that in the earlier Seattle suburb precedent case (Renton), municipalities were told that they had to have some evidence of harm caused by adult establishments, but that pretty much any evidence would do: "Justice Souter [in his dissent] asks the city to demonstrate, not merely by appeal to common sense but also with empirical data, that its ordinance will successfully lower crime. Our cases have never required that municipalities make such a showing"; and elsewhere, "in Renton, we specifically refused to set such a high bar for municipalities that want to address merely the secondary effects of protected speech. We held that a municipality may rely on any evidence that is 'reasonably believed to be relevant'..."

This move may look like a simple shift from the logic of science to the logic of law, amounting to substituting reasonabless for the scientific method. And that is not incorrect. But it is worthwhile examining the content and the authority claims of this particular invocation of resonableness, since they are not not quite the same as those of its close relative, the 'reasonable man'. The reasonable person needs no evidence at all to be empowered to act, just common sense. But city councils are said to require some evidence of harm. Their evidence collection and presentation exercise thus does not have common sense, a purely legal ingredient or input, as its only effective component. Throughout both O'Connor's judgement and the concurring judgement by Justice Kennedy, 'common sense' is consistently supplemented by a 1977 city of LA planning department study. (O'Connor puts common sense first, while Kennedy puts the study first).

How does the LA city council manage to turn its two evidentiary commodities ('common sense' and 'a study') into the effective power to regulate sex businesses? It turns out that it is not a matter of either the quality or quantity of knowledge - as one might have predicted from the more general observation that legal networks, notoriously, are not composed only of truth claims. A group of citizens, after all, might be possessed of much common sense and might additionally commission studies from a local consulting firm - but their accumulated evidence would not be exchangeable for actual regulatory power. The exchange that results in actual legal power happens only as the particular objects/actors (common sense; "the study") are combined with or mediated by city council's ongoing, permanent legal capital, namely jurisdiction.

This is accomplished through the technique of judicial review. It is a sacred principle of American as of all common law that judicial review of municipal or administrative action generally confirms official decisions, revoking them only if they are outrageous. In keeping with the long tradition of judicial deference toward executive and administrative decisions, Justice O'Connor concludes her judgement by reflecting that in the end, when all is said and done, "The LA City Council is in a better position than the judiciary to gather and evaluate data on local problems" (p 9, Alameda Books). Justice Kennedy, who is less deferential to municipal clean-up campaigns, neverteless concurs with O'Connor on this point: "the Los Angeles City Council knows the streets of Los Angeles better than we do." (P 16)

This echoes the wording of a 2000 Supreme Court decision on the related question of municipal bans on nude 
strippers, a wording that has the remarkable power to turn first-hand experience into expertise, thus deconstructing the hallowed legal distinction between ordinary fact witnesses and expert witnesses' opinion evidence:

The council members, familiar with commercial downtown Erie, are the individuals who would likely have first hand knowledge of what took place at and around nude dancing establishments there, and can make particularized, expert judgements about the resulting harmseful secondary effects. (City of Erie v. Pap's $A M, 529$ US 277 [2000] at 298).

The image of city councillors partaking of the pleasures of nude stripping and somehow proceeding to turn this "first hand" experience into expert knowledge, something which witnesses cannot do (Levi and Valverde 2001), reveals some of the specific knowledge networks of judicial review. ${ }^{13}$

It is clear in the City of Erie case that the court does not actually mean to say that, as a precondition of municipal zoning powers, city councillors need to actually partake of the plesasures of the particular strip bars that is challenging the ordinance. The council is said to have a somewhat generalized, perhaps second-hand, but nevertheless "first hand" experience of the sort of establishment to which the zoning ordinance applies. The council's knowledge is thus neither specific (they need not have actually toured Pap's AM bar) nor the result of reading sociological studies of vice districts. But somehow this rather insubstantial, almost tourist-like knowledge of strip bars is said to suffice to turn the councillors into experts.

A similar move is made in the LA case. The "streets" of LA are invoked twice by the writers of the two concurring decisions. Are these actually existing, particular streets? Their status is illuminated if one, first, notes that no street names are given, and, secondly, what happens if one tries to substitute "freeway" for "street". "The councillor on the freeway" just doesn't work as legal rhetoric, any more than "the man on the freeway" could subsitute for "the man on the street." So it is clear that "streets" does not name a physical location, but rather a type of knowledge/ experience - as in the phrase "streetwise".

And yet, the streets are not pure legal inventions. "The streets of LA" of the Supreme Court text may not be locatable on any map, but neither are they to be found in a legal dictionary alongside "the reasonable person". The LA streets of this decision are ontologically hybrid - partly mythical (as per the longstanding assocation of 'streets' with [male] wisdom about the vices of urban life), partly real (the sex shops are located on real streets), and partly legal.

Although I would need to do more research to prove this, my suspicion is that the cultural connotations of streets with middle class male flaneurs walking on them, while helpful, are not as important in this particular network as the legal institutions of jurisdiction and judicial review. By invoking the sociolegal, complex, non-physical 'street', and proceeding to imaginatively place the city councillors on it, the Supreme Court turns legal jurisdiction (Richard T Ford, 1999) into epistemological currency. The council has the legal duty to provide streets, to clean them, and so on, and the legal right to regulate traffic on them. Whether this gives the council any greater knowledge of the moral and social and economic issues involved in the regulation of pornography, or any first-hand knowledge of the condition of the particular establishment launching the legal challenge to the ordinance, is a question that is elided and excluded - precisely through the legal tool of judicial review.

\footnotetext{
${ }^{13}$ The Webbs' voluminous history of local government often refers to the 'ancient' practice of municipal corporation leaders physically marking out the limits of the town or city in question through a yearly ritual walk, an
} 
City fathers are thus portrayed as 'knowing best' what will work in their communities to prevent harms. (The gendering of councillors as men is, incidentally, crucial in this network, given the very different effects that would be achieved if courts were to muse about 'the woman of the streets' in their judgement). But, paradoxically, the harm that is alleged to flow from any one city's sexually oriented establishments is said to be the same from Renton, Washington to Detroit to New York City.

A generally pragmatic, harm-focused approach to the question of special sexual zoning thus fails to produce rational, objective, standardized regulatory policies - contrary to the usual view about American legal pragmatism, contrary to the usual view, by which social science facts and logics automatically generate rational, modernizing, policy-focused law. But neither do courts engage in a contemplation of the kind of specific local conditions that anthropologists - or local residents, for that matter - would want to highlight.

In general, I think that legal networks can accomplish amazing deconstructions of the binary opposition between particular facts and scientific knowledge that was first identified by Aristotle. The streets of which city councillors are said to have knowledge (a knowledge that is both experiential and expert, to add to the deconstructionist enterprise) exist in a mini universe beyond the dichotomoy of particular facts vs scientific findings about aggregate data. And, through some of the same processes, the knowledge of community harms generated in these legal networks also deconstructs the opposition between formalism and pragmatism, legal principle vs policy.

\section{The criminal law}

Urban law and governance is my main research interest these days, but, it is important to not create the impression that some of the knowledge moves documented above are specific to this area. Thus, a few words on another area of law may serve as conclusion.

If we go to a very different sort of legal arena, one that has been an important repository for extreme forms of national moralism, emotional longings, and symbolism - the criminal law - we also see that an apparently antipragmatic arena or network can nevertheless not only include but produce and come to rely on highly pragmatic knowledge practices. Plea bargaining, an essential part of criminal law in our day, has as one of its curious features an almost Nietzschean mechanism known as 'fact bargaining'. As Ron Levi shows, this involves treating facts as bits of power: for example, the prosecution will say, "I won't mention the gun if you agree to X or Y" (Levi 2002). Thus, the knowledge ideal of the criminal law - the full, detailed, truthful, exposition of all of the facts that multiple witnesses saw or heard - is cavalierly set aside, in favour of a knowledge practice that the most cynical foucaultian criminologist could not have invented. The strangely peaceful coexistence of these totally opposed views of truth is achieved by a simple mechanism, which is to physically separate the plea bargaining from the presentation of evidence in the courtroom.

More generally, the coexistence of pre-pragmatic, quasi-Christian ideals about trials as inquiries into the inner motives and intent of the criminal and the pragmatic efforts to document objective harm and use that as the key legal criterion is facilitated, and shielded from critical eyes, by the pedagogical legal tradition that separates the philosophical principles of the criminal law from the courses, often taught by practitioners rather than full-fledged academics, that teach law students the details of criminal procedure. Thus, when Nietzsche tried to include law, and especially the legal concept of 'mens rea', within his general critique of 'guilt, bad conscience and related matters' (Gen. of morality, $2^{\text {nd }}$ essay), he was addressing only the philosophical and moral dimension of the criminal law; he

interesting practice in which legal inscription takes a non-written form. 
was ignoring the welter of very pragmatic knowledge practices without which the whole edifice of crime, guilt, and punishment would grind to a halt.

He delighted in debunking the pretensions of German legal philosophy by showing that the key actor in penal law, the adult subject possessed of free will, is the product of a long and bloody history of practices of punishment. But a closer study of legal knowledge processes could be undertaken that would reveal that even inside the stately woodpanelled courtroom there are knowledge practices that are at odds with the law's own account of its actors. 